\title{
Destinasyon Rekabetçilik Analizi: Kapadokya Bölgesi Örneği*
}

\author{
Destination Competitiveness Analysis: The Case of Cappadocia Region
}

\author{
Mehmet Halit AKIN**, Yüksel ÖZTÜRK***, Kurtuluş KARAMUSTAFA*** \\ **(Sorumlu Yazar) Arş. Gör. Dr., Erciyes Üniversitesi, Turizm Fakültesi, Yenidoğan Mahallesi Ahmet El Biruni Caddesi, 38280, Talas, Kayseri. \\ E-posta: halitakin@erciyes.edu.tr \\ ORCID: 0000-0002-9455-0323 \\ *** Prof. Dr., Ankara Hacı Bayram Veli Üniversitesi, Turizm Fakültesi, Gölbaşı Yerleşkesi, 06830, Gölbaşı, Ankara. \\ E-posta: yuksel.ozturk@hbv.edu.tr \\ ORCID: 0000-0002-4320-5626 \\ **** Prof. Dr., Kayseri Üniversitesi Rektörlük, Mevlana Mahallesi, 15 Temmuz Yerleşkesi, Kümelievler, Erciyes Üniversitesi, Turizm Fakültesi, Yenidoğan Mahallesi \\ Ahmet El Biruni Caddesi, 38280, Talas, Kayseri. \\ E-posta: karamustafa@erciyes.edu.tr \\ ORCID: 0000-0002-6581-6276
}

MAKALE BILGILERI

Makale işlem bilgileri:

Gönderilme tarihi: 19 Aralık 2019

Düzeltme: 10 Mart 2020

Kabul: 17 Mart 2020

Anahtar sözcükler: Rekabet,

Destinasyon rekabetçiliği, Turizm, Kapadokya Bölgesi.

ARTICLE INFO

Article history:

Submitted: 19 December 2019

Resubmitted: 10 March 2020

Accepted: 17 March 2020

Key words: Competition, Destination competitiveness, Tourism, Cappadocia region.

\begin{abstract}
ÖZ
Bilgi, iletişim ve ulaşım teknolojilerindeki gelişmelerle küresel bir yapıya bürünen destinasyonlar yoğun bir rekabet ortamına girmekte ve dolayısıyla destinasyon rekabetçiliğiyle ilgili çalıșmalara ilgi gittikçe artmaktadır. Bu bilgiler ışığında bu çalışmada, önemli bir kültür turizmi destinasyonu olan Kapadokya Bölgesi temelinde destinasyon rekabetçiliğinin turistler açısından değerlendirilmesi ve ilgili bilgi birikimine birtakım katkılar olușturulması amaçlanmaktadır. Bu çalıșmanın önemi hem hedef rekabetçiliği inceleyen hem de politika geliștiren ve planlar yapanlara prensipler geliștirmek ve rehberlik etmektir. Çalıșmanın amacı doğrultusunda, konaklama işletmelerinde bırak ve topla yöntemi, Kayseri Erkilet Uluslararası Havalimanı'nda yüz yüze yöntemle uygulanan toplam 401 adet form vasıtasıyla elde edilen verilere tanımlayıcı istatistikler uygulanmıștır. Kapadokya'nın destinasyon rekabetçiliği açısından güçlü unsurlara sahip olduğu, genel anlamda rekabetçi bir destinasyon olduğu ve rekabetçilikte birincil derece önemli unsurların daimî kaynaklara, ikincil derece önemli unsurların ise destek kaynaklara dayandığı sonucuna ulaşılmıştır.
\end{abstract}

\begin{abstract}
Destinations, which have a global structure with the development in the areas related to information, communication and transportation technologies, enter an intense competitive environment and therefore, academic interest on destination competitiveness is increasing. This study aims to evaluate tourist perceptions on destination competitiveness of the Cappadocia Region, which is an important cultural destination, and hence make contributions to the relevant body of knowledge. The importance of this study is to develop principals and provide guidance for those both studying destination competitiveness and developing policies and making plans. For the purpose of the study, descriptive statistics have been applied to the data obtained from 401 questionnaires applied to the foreigners visiting the Cappadocia Region by both the drop-collect method at the accommodation enterprises and face to face method at the Kayseri Erkilet International Airport. It was concluded that Cappadocia has strong elements in terms of destination competitiveness, it is a competitive destination in general and most important primary factors are based on inherited resources and most important secondary factors are based on supporting resources in competitiveness.
\end{abstract}

\footnotetext{
* Bu çalışma, Gazi Üniversitesi Sosyal Bilimler Enstitüsü Turizm İşletmeciliği Anabilim Dalında, Prof. Dr. Yüksel Öztürk ve Prof. Dr. Kurtuluş Karamustafa danışmanlığında yazılan "Bir Turistik Destinasyon Olarak Kapadokya Bölgesinin Destinasyon Rekabetçiliği Analizi" başlıklı doktora tezinden üretilmiştir. Çalışma Erciyes Üniversitesi Bilimsel Araştırma Projeleri Birimi tarafından SDK-2017-7653 kodlu proje ile desteklenmiştir.
}

\section{GiRiş}

Uluslararası turizm hareketlerinin dünya ekonomisine doğrudan ve dolaylı etkileri sonucunda turizm sektörü küresel bir ekonomik güç haline gelmekte (Fuller 2013) ve sektörün sürekli büyüyen bir yapıya sahip olması nedeniyle destinas- 
yonlar, küresel pazarda rekabetçi güçlerini ve pazar paylarını sürekli artırmaya yönelmektedirler (Bahar ve Kozak 2005: 38). Bu unsurların yanı s1ra küreselleşmenin ve teknolojinin etkisiyle destinasyonlar arasındaki ticari duvarların kalkması (Karabulut 2004) turizmde rekabetin oluşmasına, önem kazanmasına ve dikkate alınmasına sebep olmaktadır. Turizm için önemli bir bölgesel ürün niteliğinde olan destinasyonların rekabetçi pozisyonları, turizm sektörünün küresel ticaret ortamında değer kazanmasına veya kaybetmesine sebep olmaktadır (Meng 2006). Bu nedenle destinasyon rekabetçiliği kavramı turizm sektörünün rekabetçiliği hususunda ön plana çıkmaktadır.

Destinasyonlar, sahip oldukları çekicilik unsurları bakımından genel olarak farklılık göstermektedirler. Rekabetçilik bakımından öne çıkmak isteyen destinasyonlar ise bu farklılıklara odaklanmaktadırlar (Güzel 2010). Ancak, küreselleşme ve iletişim ağının genişlemesi gibi teknolojik gelişimlerle bu farklılıkların, destinasyon yönetimi ve pazarlanmasında tek başına yeterli olmadığ1 görülmüştür (Kartal 2010). Bu noktada, küresel ticaret ortamında ön plana çıkmak isteyen destinasyonlar için destinasyon yönetiminin ve pazarlanmasının yanı sıra rekabetçilik bakımından sahip olunan güçlü ve zayıf yönlerin tespit edilmesinin gittikçe önem kazandığı söylenebilir.

Çeşitli destinasyonlara yönelik yapılmış birçok rekabetçilik analizi araştırmaları bulunmasına karşın (Ritchie ve Crouch 1993; Heath 2002; Omerzel 2006; Ferreira ve Estevao 2009; Tsai vd. 2009; Hallman vd. 2014; Gupta ve Singh 2019) alternatif turizm içerisinde önemli bir konuma sahip olan kültür turizmi faaliyetlerini içeren destinasyonlara ve özellikle sınırlı sayıda ürün çeşitliliğine sahip destinasyonlara yönelik yapılmış araştırmaların oldukça sınırlı sayıda olduğu görülmektedir. Bununla birlikte, Türkiye' nin önemli bir kültür turizmi destinasyonu olan Kapadokya Bölgesi'nin bazı turizm verileri ${ }^{1}$ göz önüne

\footnotetext{
${ }^{1}$ Kültür ve Turizm Bakanlığ1 (2019) verilerine göre, 2018 y1l1 ortalama kalış süresi belediye belgesi tesisler için 1,86 ve turizm işletme belgeli tesisler için ise 1,73; ortalama doluluk oranı belediye belgesi tesisler için yüzde 35,61 ve turizm işletme belgeli tesisler için ise yüzde 48,80 'dir.
}

alındığında, bölgenin sunmuş olduğu turizm arz unsurlarıla bölgeye yönelik turizm talebindeki çeşitliliğe ve teknolojik gelişimlere ve küreselleşmeye bağlı olarak da destinasyon olarak sahip olduğu birtakım zayıflıklarla beraber tehditlerle de karşı karşıya olduğu düşünülmektedir. Dolayısıyla bu bilgiler göz önünde bulundurularak Kapadokya Bölgesi araştırmanın hedef destinasyonu olarak seçilmiştir.

Yukarıda verilen bilgilere dayalı olarak bu çalışmada, turizm sektörünün en önemli bileşenini temsil eden arz unsuruna dayalı olarak, özellikle sınırlı sayıda ürün çeşitliliğine sahip olan bir kültür turizmi destinasyonu olarak Kapadokya Bölgesi'nin destinasyon rekabetçiliğinin değerlendirmesiyle araştırmacılara ve uygulayıcılara yönelik özgün bilgi ve önerilerin sunulmasının yanı sıra ilgili alan yazına farklı katkıların oluşturulması amaçlanmıştır. Araştırma kapsamında, bölgenin güçlü ve zayıf yönlerinin belirlenmesinin yanı sıra arz yönlü beklentilerin saptanmasıyla politika belirleyicilere ve sektör temsilcilerine, sunulacak bilgi birikimiyle ise ilgili alanda araştırma yapacaklara yönelik yol gösterici katk1ların oluşturulması beklenmektedir.

\section{KAVRAMSAL ÇERÇEVE}

Turizm sektörüyle ilişkili bütün unsurların ulusal ve uluslararası piyasada faaliyetlerine devam edebilmeleri için rekabet kaçınılmaz bir unsur olarak görülmektedir (Zengin ve Uyar 2012). Ancak küreselleşme, teknolojik gelişimler, tüketicilerin bilinçlenmesi gibi etkenlerin ortaya çıkmasıyla birlikte destinasyonların içinde bulundukları rekabet ortamı daha zorlu bir hale gelmiştir. Ayrıca destinasyon yöneticilerinin, turizm sektöründe rekabet edebilmek ve başarılı olabilmek için yeterli olduğunu düşündükleri turist, destinasyon kaynakları, düşük maliyetler, cazip döviz kurları gibi unsurların tek başına yeterli olmadığ 1 fark edilmeye başlamıştır (Bordas 1994). Bu doğrultuda hem araştırmacılar hem de yöneticiler tarafından destinasyonları rekabetçi kılan unsurlara verilen önemin giderek arttığı söylenebilir.

Esasen, Porter'ın (1990) ulusların rekabet edebilirliği konusundaki çalışmalarıyla birlikte başlayan rekabet ve rekabetçilik araştırmalarına 
olan ilgi özellikle, bu alanda en iyi uygulamaları geliştirmek isteyen araştırmacılar tarafından devam ettirilmiş ve bu konuda birçok araştırma yapılmıştır (Porter 1990; Ritchie ve Crouch 1993; Heath 2002; Dwyer ve Kim 2003; Ferreira ve Estevao 2009; Tsai vd. 2009; Hallman vd. 2014; Gupta ve Singh 2019). Özellikle destinasyon rekabetçiliği ilgili yapılan araştırmalar incelendiğinde, genellikle çeşitli turizm destinasyonlarının rekabetçiliklerinin tanımlanması, modellenmesi ve ölçülmesinin yanı sıra belirlenmiş olan rekabetçi pozisyonlarının geliştirilmesine yoğunlaştıkları görülmektedir (Das ve DiRienzo 2009).

Destinasyonlar birçok farklı bileşen grubunu kapsamalarından dolayı karmaşık bir yapıya sahiptirler (Morgan vd. 2004). Bu nedenle, birbirleriyle kıyaslamalı olarak farklı özellikler gösterebilen her bir destinasyonun rekabetçiliğine yönelik göstergeler de bu doğrultuda farklılık gösterebilmektedir. Dolayısıyla bu göstergeler geniş bir alan yazını kapsamaktadır (Gupta ve Singh 2015). İlgili alan yazın incelendiğinde, destinasyonların rekabetçi pozisyonlarının belirlenmesi ve destinasyon rekabetçiliği göstergelerinin ortaya konması adına yapılan birçok araştırmayla karşılaşılmaktadır (Porter 1990; Crouch ve Ritchie 1999; Heath 2002; Dwyer ve Kim 2003; Ferreira ve Estevao 2009).

Destinasyon rekabetçiliği göstergelerini bir model temelinde ortaya koyan araştırmalardan biri olan Porter'ın (1990) "Elmas Modeli"; devlet ve şans faktörleri olmak üzere iki dış faktör tarafından desteklenen dört analitik boyut (temel faktörler); faktör koşulları, talep koşulları, ilgili ve destek sektörleri ve firma stratejisi, yapı ve rekabet faktörlerinden oluşmaktadır. Crouch ve Ritchie'nin (1999) "Kavramsal Rekabet Modeli" öz kaynaklar - çekicilik faktörleri, destekleyici faktörler-kaynaklar, destinasyon yönetimi ve eleme (nitelik) - yükseltme belirleyicileri iç faktörleri ve bu iç faktörleri etkileyen rekabetçi (mikro) çevreler ve küresel (makro) çevreler dış faktörlerinden oluşmaktadır. Son olarak, Dwyer ve Kim'in (2003) “Bütünleştirilmiş Rekabet Modeli" ise daimî kaynaklar, yapay kaynaklar, destek kaynaklar, destinasyon yönetimi, durumsal koşullar ve talep koşulları olmak üzere kategoriler altında toplamıştır. Bu faktörlerin güçlü veya zayıflık durumlarının destinasyon rekabetçiliğinin en temel göstergesi olduğu ifade edilmiştir (Dwyer ve Kim 2003).

Bütün modeller bir bütün olarak incelendiğinde, genel olarak bir modelin diğerini temel alarak ve eksiklerini tamamlamaya odaklanarak geliştirildiği ancak her bir modelin farklı temel dayanağının bulunduğu görülmektedir. Ayrıca Porter'ın (1990) modelinin temelde bütün sektörlerdeki rekabetçi pozisyonların belirlenmesine odakland1$\breve{g}$, diğer modellerin ise özellikle destinasyonlar özelinde rekabetçi pozisyonların belirlenmesine odaklandıkları görülmektedir.

\section{YÖNTEM}

Bütün şartlarda bütün destinasyonlara uygulanabilen bir destinasyon rekabetçiliği modeli bulunmaması nedeniyle (Yüzbaşığlu vd. 2016: 174) bu araştırmada, destinasyon rekabetçiliğine etki eden ifadelerin saptanması için toplamda altı faktör temelinde oluşturulan ve arz ve talep yanlı göstergeleri içeren Dwyer ve Kim'in (2003) “Turizm Destinasyonu Rekabetçiliği - Tourism Destination Competitiveness" ölçeğinden yararlanılmıştır. Ancak ölçek içerisinde yer alan casino turizmi, ulusal turizm örgütü gibi ifadeler Kapadokya Bölgesi'ne, destinasyonun vizyonu, yabancı yatırımcıların varlığı, iş etiği ilkeleri gibi ifadeler ise araştırmanın evrenini oluşturan turistlere uygun olmadığı için çıkarılmıştır. Konaklama tesislerinin kalitesi/çeşitliliği gibi ikili ifadeler ise ayrıştırılarak ayrı ayrı ifadeler olarak eklenmiştir. Bahsedilen ekleme-çıkarma süreçlerinde, Dwyer ve Kim'in (2003) hazırlamış olduğu ve ilgili ölçeği oluştururken yararlandığı "Destinasyon Rekabetçiliğinin Seçilmiş GöstergeleriSelected Indicators of Destination Competitiveness" tablosu temel alınmıştır. Sonuç olarak, 62 ifadeden oluşan ölçekte 5’li Likert tipi ölçek kullanılmıştır ve katılımcıların demografik özelliklerini belirlemeye yönelik sorulara da yer verilmiştir. Ayrıca, ilgili ölçeğin zorlanmış ölçek olmaması ve dolayısıyla katılımcıların bilgisinin olmadığ 1 ifadelere cevap vermeye yönlendirilmemeleri gerektiği göz önünde bulundurularak, ölçekte, analizlere dâhil edilmiş olan $0=$ bilmiyorum / emin değilim seçeneğine de yer verilmiştir. 
Özgün hali İngilizce olan ölçek, araştırma kapsamında da İngilizce olarak hazırlanmış ve ölçekteki ifadelerde olası anlaşılmazlıkları ortadan kaldırmak için bir pilot test yapılmıştır. Pilot test, niceliksel olarak yeterli olduğu düşünülen 32 katılımcı üzerinde uygulanmıştır (Hertzog 2008; Johanson ve Brook 2010; Van Belle 2012). Katılımclların ölçeği doldururken ve doldurduktan sonraki eğilimleri izlenmiş, ölçeği genel manada anlaşılır kabul ettikleri ve ifadelerin kısa olması nedeniyle ölçeği cevaplamaya istekli oldukları gözlemlenmiştir. Dolayısıyla ölçeğin içerik geçerliği bu şekilde sağlanmıştır. Ayrıca ölçeğin güvenirliğini test etmek amaciyla Cronbach's Alpha katsayısı hesaplanmış, güvenilirlik seviyesinin tatmin edici düzeyde olduğu görülmüştür $(\alpha=0,901)$. Bir ölçeğin geçerli sayılabilmesi için güvenirlik katsayısının yüksek olması, yeterli olmamakla birlikte, birincil koşul olarak kabul edilmektedir (Karasar 2003). Ölçeğin geçerliğini desteklemek amacıyla araştırma konusuyla ilişkili iki uzman görüşü alınmış ve ilgili ölçeğin amaçlanan değerlendirmelerin yapılabilmesi bakımından geçerliğe sahip olduğu desteklenmiştir. Ayrıca, önceki araştırmalara dayanarak ölçeğin geçerliğinin desteklendiği süreci içeren nomolojik geçerlilik (Hair vd. 2010) kapsamında alan yazın taraması yapılmış (Omerzel 2006; Armenski vd. 2011; Mulec ve Wise 2013) ve çalışmanın ölçeğinin geçerli olarak kabul edildiği görülmüştür.

Önemli bir kültür turizmi kapasitesine sahip olan Kapadokya Bölgesi'ne yönelik yapılmış bir destinasyon rekabetçiliği analizi araştırmasına rastlanmamış olması nedeniyle bu araştırmada uygulama alanı olarak Kapadokya Bölgesi belirlenmiştir. Kültür ve Turizm Bakanlığı, Konaklama İstatistikleri'ne (2019) göre, Kapadokya Bölgesi' ne 2018 yılında 872 bin 336 yabancı turist gelmiştir (Kültür ve Turizm Bakanlığı, 2019). Bu sayı aynı zamanda araştırmanın evrenini oluşturmaktadır. Bütün turistlere ulaşmanın zaman ve maddi yetersizliklerden dolayı mümkün olmaması nedeniyle bu araştırmada örneklem belirlemesi yapılmıştır. Araştırmanın amacına ulaşması için uygun olduğu düşünülen olasıllğa dayalı olmayan örneklemelerden gayeli (amaçsal) örneklem ve kolayda örneklem türleri birlikte kullanılarak araştırmanın örneklemi olarak seçil- miştir. Ölçeği dolduran kişilerin araştırmanın evrenini temsil edecek kişilerden seçilmesine dikkat edilmiştir.

Araştırmanın örneklemi, yüzde 95 güven düzeyinde yüzde 5 hata payıla 384 olarak hesaplanmıştır (www.surveysystem.com). Örneklem büyüklüğüne bakılmaksızın amaçlanan sonuçlara ulaşmak için 384 örneklem sayısı yeterlidir (Karasar 2003; Yazıcı 2018). Ayrıca veri analizlerinde amaca ulaşabilmek için örneklem sayısının ölçekteki ifadelerin en az beş katı arasında olması gerektiği önermesi dikkate alındığında (Büyüköztürk, 2002), 384 örneklem sayısının yeterli olduğu söylenebilir. Ölçek, Kapadokya Bölgesi'ndeki işletmelerde 12-27 Temmuz 2019 tarihleri arasında bırak-topla yöntemiyle Kayseri Havaalanı İç Hatlar Gidiş Terminali'nde ise 29 Temmuz-11 Ağustos 2019 tarihleri arasında yüz yüze yöntemiyle uygulanmıştır. Toplamda 428 form toplanmış, bunlardan bütün ifadelerde aynı seçeneği işaretleyerek önem vermeden doldurulduğu düşünülen ve eksik veya hatalı doldurulan 27 form değerlendirmeye alınmamıştır. Dolayısıyla 401 adet form analizlere dâhil edilmiştir. Katılımcıların demografik özelliklerinin dağılımlarının yanı sıra bölgenin rekabetçilik bakımından güçlü ve zayıf yönlerini saptamak için ifadelerin ortalamalarının hesaplanması adına tanımlayıcı istatistiklerden yararlanılmıştır.

\section{ANALIZ VE BULGULAR}

Destinasyon rekabetçiliği ile ilgili alan yazın incelendiğinde (Enright ve Newton 2004; Bahar ve Kozak 2005; Chens vd. 2008; Pansiri 2014; Yüzbaşığlu vd. 2016), birçok çalışmanın destinasyonların rekabetçilik analizleri ile güçlü ve zayıf yönlerinin belirlenmesi hususunda frekans analizlerinden yararlandığı görülmektedir. Demografik özelliklerin sıklık dağılımlarının yanı sıra diğer verilerin merkezi eğilim ölçüsünün belirlenmesi için ortalamalarının ve verilerin ortalamaya yakınlık derecelerinin belirlenmesi için standart sapmalarının hesaplandığ 1 bu çalışma kapsamında da değerlendirmeler, ortalama ve standart sapma değerleri üzerinden yapılmıştır.

Demografik özelliklere yönelik tanımlayıcı istatistiklere göre, katılımcıların genel çoğunluğu- 
nu (yüzde 41,6) 30 ve altı yaş aralığında, (yüzde 26,9) işçi statüsüne sahip olan ve (yüzde 41,2) Asya-Pasifik ülkelerinden olan katılımcılar oluşturmaktadır. Ayrıca katılımciların yüzde 51,6'sı erkek, yüzde 48,4'ü kadın, genel çoğunluğu (yüzde 66,3) evli, yüzde 33,7'si ise bekârdır. Ayrıca katılımcıların eğitim durumlarına göre dağılımları şöyledir: yüzde 20 'si ilk ve orta öğretim, yüzde $50,6^{\prime}$ sı ön lisans ve lisans ve yüzde $29,4^{\prime}$ ü ise lisansüstü eğitim derecesine sahiptir. Son olarak, katılımcılar aylık ortalama gelir bakımından daha çok sırasıyla yüzde 25,2 ve yüzde 29,4 oranlariyla 2.000 ABD dolar1 ve alt1 ve 2.001-4.000 ABD doları aralıklarında gelire sahiptir.

Bölgenin destinasyon rekabetçiliği bakımından güçlü ve zayıf yönlerinin belirlenmesi için katılımcların bütün ifadelere yönelik ortalama değerleri ve standart sapmaları incelendiğinde; turistlere göre, Kapadokya Bölgesi'nin destinasyon rekabetçiliği bakımından en güçlü olduğu yönler; (a) doğal güzellikleri (örneğin, peri bacaları, yeraltı şehirleri), (b) zengin sanatsal ve mimari özellikleri, (c) zengin kültürel alanları ve (ç) konaklama tesislerinin çeşitliliği olarak sıralanabilir. En zayıf olduğu yönler ise (a) su aktiviteleri, (b) spor faaliyetlerinin çeşitliliği, (c) vize maliyetlerinin yüksekliği ve (ç) vizeyle ilgili yasal işlemlerin çokluğu olarak sıralanabilir. Katılımcıların tüm ifadelere yönelik yanıtlarının genel ortalaması incelendiğinde, turistlerin Kapadokya Bölgesi'ni önermeler bakımından genel anlamda rekabetçi olarak gördüğü diğer bir ifadeyle sahip olunan unsurlar bakımından turistlere göre Kapadokya Bölgesi'nin genel anlamda güçlü unsurlara sahip olduğu yorumu yapılabilir.

Daimî kaynaklara yönelik katılımcıların ortalama değerleri incelendiğinde, bütün kaynakların genel anlamda ortalamanın üzerinde değerlere sahip oldukları görülmektedir. Bu manada, daimî kaynaklarının bölgenin destinasyon rekabetçiliğinde sahip olduğu güçlü yönleri ifade ettikleri söylenebilir. Ayrıca bu ifadelerin en yüksek değerlere sahip olması, önemli bir kültür turizmi destinasyonu olan Kapadokya Bölgesi'nin sahip olduğu kültürel, tarihi ve doğal güzellikleriyle ilişkilendirilebilir.

Yapay kaynaklarda ise birçok ifadenin ortalamanın üzerinde bir değere sahip oldukları görül- mektedir. Bununla birlikte, özellikle macera aktiviteleri, konaklama tesislerinin kalitesi, konaklama tesislerinin çeşitliliğ gibi ifadelerin bölgenin rekabetçiliğinde güçlü unsurları oluşturdukları görülmektedir. Bu ifadeler, bölgenin sahip olduğu kaliteli hizmetler sunan konaklama tesislerinin butik, apart, yıldızlı oteller gibi birçok çeşide sahip olması ve bölgenin en önemli ve en çok talep edilen faaliyetlerinden biri olan balon turizmiyle ilişkilidir. En düşük ortalamalara sahip olan su aktiviteleri, parklar ve spor faaliyetleri gibi unsurlar ise Kapadokya Bölgesi'nin daha rekabetçi bir konuma sahip olmak için güçlendirmesi gereken unsurları oluşturmaktadırlar. Su aktiviteleriyle ilgili ortalamanın düşük olması bölgenin coğrafik özelliklerinden dolayı kurak bir iklime sahip olmasıyla ilişkilendirilebilirken diğer ifadelerin değerlerinin düşük olması bu doğrultuda turistik yatırımların yeteri düzeyde yapılmamasıyla ilişkilendirilebilir. Sonuç olarak, yer alan değerlere göre Kapadokya Bölgesi'nin yapay kaynaklar ve onun birtakım alt ifadeleri bakımından daha rekabetçi konuma sahip olduğu söylenebilir.

Turizm sektörüyle entegre faaliyetleri kapsayan destek kaynaklarda genel olarak ortalamanın üzerinde bir değere sahiptir. İfadelerde en yüksek ortalamaya turist güvenliği ve emniyetinin yeterliliği, yerel halkın turistlere yönelik cana yakınlık derecesi gibi ifadeler, en düşük ortalamaya ise vizeyle ilgili yasal işlemlerin çokluğu ifadesi sahiptir. Türk insanının genel olarak bütün yabancılara karşı sıcakkanlı olması ve bir bütün olarak Türkiye genelinde güven ortamının var olması doğrultusunda yerel halkın turistlere yönelik cana yakınlık derecesi ve turist güvenliği ve emniyetinin yeterliliği ifadelerinin yüksek ortalamaya sahip olmaları beklenen bir sonuçtur. Vizeyle ilgili ifadelerin değerlerinin düşük olması ise Türkiye içerisindeki yasal prosedürlerle ilişkilendirilebilir. Bu manada, en yüksek ortalamaya sahip olan ifadelerin korunmasının ve en düşük ortalamaya sahip olan ifadelerin değerlerinin yükseltilmesine yönelik faaliyetlerin yürütülmesinin bölgenin destinasyon rekabetçiliği konumunu yükseltmek ve sürdürülebilir kılmak için gerekli olan adımlar olduğu söylenebilir. 
Destinasyon Rekabetçilik Analizi: Kapadokya Bölgesi Örneği

Tablo 1. Katılımcıların Daimî Kaynaklara ve Yapay Kaynaklara Yönelik Ortalama ve Standart Sapma Değerleri

\begin{tabular}{|c|c|c|c|c|}
\hline & No & ifadeler & $\bar{x}$ & S.S. \\
\hline Daimî & 1. & İklimi & 3,81 & 1,04 \\
\hline \multirow[t]{10}{*}{ Kaynaklar } & 2. & Destinasyonun hijyenikliği & 3,62 & 0,99 \\
\hline & 3. & Doğal güzellikleri (örneğin, peri bacaları, yeraltı şehirleri) & 4,65 & 0,60 \\
\hline & 4. & Bozulmamış doğası & 3,92 & 1,12 \\
\hline & 5. & Flora ve faunası (bitki ve hayvan türleri) & 2,90 & 1,37 \\
\hline & 6. & Milli parkları & 3,92 & 1,29 \\
\hline & 7. & Zengin sanatsal ve mimari özellikleri & 4,03 & 0,97 \\
\hline & 8. & Zengin geleneksel sanatları (örneğin, çömlekçilik, dokumacılık, seramik, oymacılık) & 3,86 & 1,19 \\
\hline & 9. & Mutfak (yemek) çeşitliliği & 3,49 & 1,11 \\
\hline & 10. & Zengin kültürel alanları (örneğin, müzeleri, tarihi yerleri ve sit alanları) & 4,01 & 1,19 \\
\hline & & Genel Ortalama & 3,82 & \\
\hline Yapay & 1. & Su aktiviteleri (örneğin; yüzme, sörf, tekne gezisi) & 1,71 & 1,40 \\
\hline \multirow[t]{21}{*}{ Kaynaklar } & 2. & Doğa aktiviteleri (örneğin; doğa yürüyüşü, kamp alanları, kuş gözlemciliği) & 3,44 & 1,63 \\
\hline & 3. & Macera aktiviteleri (örneğin; balon, kayak, rafting, paraşüt) & 3,51 & 1,73 \\
\hline & 4. & Eğlence parkları/tema parkları & 2,25 & 1,73 \\
\hline & 5. & Eğlence hizmetlerinin (örneğin, gece hayatı, tiyatro, sinema) kalitesi & 2,82 & 1,58 \\
\hline & 6. & Eğlence hizmetlerinin (örneğin, gece hayatı, tiyatro, sinema) çeşitliliği & 2,85 & 1,57 \\
\hline & 7. & Festivallerin/özel etkinliklerin çeşitliliği & 2,59 & 1,82 \\
\hline & 8. & Konaklama tesislerinin kalitesi & 4,07 & 0,96 \\
\hline & 9. & Konaklama tesislerinin çeşitliliği & 4,21 & 1,01 \\
\hline & 10. & Havalananında sunulan hizmetlerin kalitesi & 2,74 & 1,15 \\
\hline & 11. & Turist rehberliği ve danışma hizmetlerinin yeterliliği & 3,34 & 1,11 \\
\hline & 12. & Yerel turizm ulaşım sistemlerinin yeterliliği & 3,44 & 1,28 \\
\hline & 13. & Yerel turizm ulaşım sistemlerinin kalitesi & 3,43 & 1,30 \\
\hline & 14. & Turistlerin doğal alanlara erişebilirliği & 3,59 & 1,13 \\
\hline & 15. & Toplantı (kongre) tesislerinin kalitesi & 2,10 & 1,82 \\
\hline & 16. & Yiyecek ve içecek işletmelerinin kalitesi & 3,48 & 1,19 \\
\hline & 17. & Boş zaman değerlendirme aktivitelerinin çeşitliliği & 3,17 & 1,31 \\
\hline & 18. & Spor faaliyetlerinin (örneğin, golf, tenis, futbol tesisleri) çeşitliliği & 1,87 & 1,45 \\
\hline & 19. & Alışveriş olanaklarının çeşitliliği & 3,03 & 1,36 \\
\hline & 20. & Alışveriş tesislerinde sunulan ürünlerin kalitesi & 3,19 & 1,34 \\
\hline & 21. & Turistlere alışveriş ürünlerine harcadıkları paranın karşılığının verilmesi düzeyi & 3,55 & 1,25 \\
\hline & \multicolumn{2}{|c|}{ Genel Ortalama } & 3,06 & \\
\hline
\end{tabular}

Destinasyon yönetimine yönelik ortalama değerler incelendiğinde, daimî kaynaklarla benzer şekilde bütün kaynakların genel anlamda ortalamanın üzerinde değerlere sahip oldukları görülmektedir. Özellikle, destinasyonun olumlu imaj düzeyi ve destinasyon ürünleriyle turist tercihleri arasındaki uyumluluk düzeyi gibi ifadeler bir sistem olarak destinasyon yönetiminde ve destinasyonların tercih edilebilirliklerinde oldukça önemlidirler. Dolayısıyla bölgenin uluslararası düzeyde pozitif algılamalara sahip olması ve talebin istek ve arzularını göz önünde bulunduran hizmet sunucularının var olmasıyla ilişkili olan bu ifadeler, bölgenin destinasyon rekabetçiliğinde önemli unsurları temsil etmektedirler.

Tablo 3'e göre, durumsal koşullar altında yer alan bütün ifadeler ortalamanın üzerinde değer- 
Mehmet Halit Akın - Yüksel Öztürk - Kurtuluş Karamustafa

Tablo 2. Katılımcıların Destek Kaynaklara ve Destinasyon Yönetimine Yönelik Ortalama ve Standart Sapma Değerleri

\begin{tabular}{|c|c|c|c|c|}
\hline & No & ifadeler & $\bar{x}$ & S.S. \\
\hline Destek & 1. & Turistlere yönelik sağlık hizmetlerinin yeterliliği & 2,45 & 1,99 \\
\hline \multirow[t]{13}{*}{ Kaynaklar } & 2. & Banka ve döviz bürolarının yeterliliği & 3,27 & 1,58 \\
\hline & 3. & Turistlere yönelik iletişim sistemlerinin yeterliliği & 2,74 & 1,50 \\
\hline & 4. & Destinasyonun ulaşım olanaklarının (seferlerinin) sıklığı & 3,14 & 1,32 \\
\hline & 5. & Turizm altyapısının turist ihtiyaçlarını karşılayabilme yeterliliği & 3,43 & 1,14 \\
\hline & 6. & Destinasyonun diğer destinasyonlara olan uzaklığı/uçuş süreleri & 3,26 & 0,97 \\
\hline & 7. & Destinasyona olan uçuş sayılarının yeterliliği & 2,83 & 1,20 \\
\hline & 8. & Turist güvenliği ve emniyetinin yeterliliği & 4,35 & 0,87 \\
\hline & 9. & Türkiye'deki gümrük bürolarının yeterliliği & 2,49 & 1,73 \\
\hline & 10. & Türkiye'deki gümrük bürosu görevlilerinin tutum/tavırları & 2,58 & 1,69 \\
\hline & 11. & Vize maliyetlerinin yüksekliği & 1,98 & 1,70 \\
\hline & 12. & Vize ile ilgili yasal işlemlerin çokluğu & 2,01 & 1,76 \\
\hline & 13. & Yerel halkın turistlere yönelik cana yakınlık derecesi & 3,94 & 1,34 \\
\hline & \multicolumn{2}{|c|}{ Genel Ortalama } & 2,95 & \\
\hline Destinasyon & 1. & Destinasyonun olumlu imaj düzeyi & 4,36 & 0,81 \\
\hline \multirow[t]{8}{*}{ Yönetimi } & 2. & Destinasyon deneyimlerinin etkin bir paket halinde sunulma düzeyi & 3,69 & 1,20 \\
\hline & 3. & Turizm çalışanlarının değişen turistlerin ihtiyaçlarına cevap verebilme yetenekleri & 3,84 & 1,07 \\
\hline & 4. & Destinasyon ürünleri ile turist tercihleri arasındaki uyumluluk düzeyi & 3,77 & 1,25 \\
\hline & 5. & Kamu çalışanlarının turizm alanındaki eğitim düzeyleri & 2,73 & 1,57 \\
\hline & 6. & Özel sektör çalışanlarının turizm alanındaki eğitim düzeyleri & 3,07 & 1,45 \\
\hline & 7. & Destinasyondaki sektörel gelişimin turistlerin ihtiyaçlarına cevap verebilme düzeyi & 3,57 & 1,19 \\
\hline & 8. & Turizm işletmelerinin değişen turistlerin ihtiyaçlarına cevap verebilme yetenekleri & 3,49 & 2,41 \\
\hline & \multicolumn{2}{|c|}{ Genel Ortalama } & 3,56 & \\
\hline
\end{tabular}

lere sahiptirler. Dolayısıyla durumsal koşullar bakımından bölgenin rekabetçi bir konuma sahip olduğu söylenebilir. Özellikle destinasyonun sahip olduğu egzotikliğin (ilginç çekiciliklerin) yeterliliği ve turistlere konaklamak için harcadıkları paranın karşılı̆̆ının verilme düzeyi ifadeleri bölgenin sahip olduğu daha güçlü yönleri oluşturmaktadırlar. Egzotiklik, Kapadokya Bölgesi'nin sahip olduğu peri bacaları, çömlekçiliği, sanatsal özellikleri gibi birçok eşsiz güzellikleriyle ilişkilendirilebilirken turistlere konaklamak için harcadıkları paranın karşılı̆̆ının verilme düzeyi, bölgenin konaklama tesislerinin çeşitlilik ve kalite bakımından oldukça yüksek ortalamalara sahip olmasıyla ilişkilendirilebilmektedir.

Son olarak katılımcıların talep koşullarına yönelik değerleri incelendiğinde ise talep koşullarını oluşturan her iki ifadenin de ortalamanın üzerinde bir değere sahip olduğu ve bölgenin talep koşulları bakımından oldukça rekabetçi bir konuma sahip olduğu görülmektedir. Ancak bu ifadelerin değerlerinin olabildiğince yüksek seviyelere getirilmesi bölgenin uluslararası düzeyde tanınırlığının artmasını ifade etmektedir, dolayısıyla bölgenin rekabetçiliği için bu ifadeler üzerinde sürekli durulması gerekmektedir.

Destinasyon rekabetçiliğini oluşturan bütün faktörlerin genel ortalamalarının bir bütün olarak değerlendirilmesi, faktörlerin birbirleriyle kıyaslanabilmeleri açısından oldukça önemlidir. Buna göre, bütün faktörler genel ortalamalarına göre sıralandırılmış ve sırasıyla daimî kaynaklar $(\bar{X}=3,82)$, talep koşulları $(\bar{X}=3,77)$, destinasyon yönetimi $(\bar{X}=3,56)$, durumsal $\operatorname{koşullar}(\bar{X}=3,17)$, yapay kaynaklar $(\bar{X}=3,06)$ ve destek kaynaklar ( $\bar{X}=2,95$ ) faktörleri yer almıştır. Bu dağılıma göre, bütün faktörler ortalamanın üzerinde bir genel 
Destinasyon Rekabetçilik Analizi: Kapadokya Bölgesi Örneği

Tablo 3. Katılımcıların Durumsal Koşullara ve Talep Koşullarına Yönelik Ortalama ve Standart Sapma Değerleri

\begin{tabular}{lllrr}
\hline & No & ifadeler & $\bar{x}$ & S.S. \\
\hline Durumsal & 1. & Destinasyonun sahip olduğu egzotikliğin (ilginç çekiciliklerin) yeterliliği & 4,22 & 0,96 \\
Koşullar & 2. & Turist gönderen pazarlardan destinasyona olan uçuşların fiyatı & 3,09 & 1,13 \\
& 3. & Destinasyona yönelik hazırlanmış olan paket turların fiyatı & 2,65 & 1,49 \\
& 4. & Rakiplere kıyasla Kapadokya Bölgesi'nde yapılan tatilin fiyatı & 2,93 & 1,23 \\
& 5. & Turistlere konaklamak için harcadıkları paranın karşılığının verilme düzeyi & 3,91 & 0,95 \\
& 6. & Destinasyondaki döviz kuru hareketlerinin turistlerin seyahat kararlarına etki düzeyi & 3,30 & 1,53 \\
& 7. & Destinasyonda turistlere yönelik işlenen suçların görülme sıklı̆̆ı & 1,46 & 1,48 \\
& 8. & Turistlere turizm deneyimlerine harcadıkları paranın karşı̆ı̆ının verilmesi düzeyi & 3,82 & 0,95 \\
\hline Talep & Genel Ortalama & 3,17 & 3,79 \\
Koşulları & 2. & Bir bütün olarak Kapadokya Bölgesi'nin uluslararası bilinirlik düzeyi & 1,31 \\
\hline & Gestinasyonun çekicilik unsurlarının uluslararası bilinirlik düzeyi & 3,77 & 1,36 \\
\hline
\end{tabular}

ortalamaya sahiptir, destek kaynaklar ise diğer faktörlere kıyasla Kapadokya Bölgesi'nin rekabetçiliğinde daha zayıf unsurları temsil etmektedir. Daimî kaynaklar ve altında yer alan ifadeler ise diğer ifadelere kıyasla bölgenin rekabetçilik bakımından sahip olduğu güçlü unsurları oluşturmaktadir.

\section{SONUÇ VE ÖNERILER}

Destinasyon rekabetçiliğinin ölçülmesi, modellenmesi ve geliştirilmesine yönelik çalışmaların gittikçe önem kazandığı ve bu yönde artan bir ilgiye sahip olduğu aşikârdır. Bu alanda oluşan alan yazın bir bütün olarak değerlendirildiğinde oluşan genel izlenim, rekabetçi pozisyonların belirlenmesinde; (a) ulusal ekonomiden ziyade uluslararası ekonomiye, (b) ekonominin çok boyutlu alanlarıyla birlikte yönetimsel ve stratejik unsurlara, (c) işletme ve sektörler bazında rekabet avantajı sağlayacak unsurlara, (ç) sürdürülebilirlik yaklaşımının benimsenmesine ve insan faktörüne stratejik öneminin verilmesine ve (d) yerel halkın yaşam standartlarının yanı sıra hem arz koşullarına hem de talep koşullarına odaklanılması gerektiğidir. Bu unsurların birçoğu aynı zamanda, bölgesel, ulusal ve uluslararası düzeydeki destinasyon yönetimi politikalarında göz önünde bulundurulması gereken unsurlardır.

Kapadokya Bölgesi'nin güçlü ve zayıf yönleri- nin belirlenmesi için yapılan destinasyon rekabetçiliği analizleri neticesinde şu sonuçlar elde edilmiştir: Katılımcıların bölgeyi genel anlamda rekabetçi bir destinasyon olarak algıladıkları görülmektedir. Ayrıca bölgenin doğal güzellikler, zengin sanatsal ve mimari özellikler, zengin kültürel alanlar, konaklama tesislerinin çeşitliliği ve destinasyonun egzotikliği gibi güçlü unsurlara sahip olduğu anlaşılmaktadır. Bununla birlikte, daimî kaynaklar ve yapay kaynaklar faktörleri altında yer alan bütün ifadelerin genel anlamda ortalamanın üzerinde oldukları saptanmıştır. Özellikle doğal güzellikleri, zengin sanatsal ve mimari özellikleri ve konaklama tesislerinin kalitesi ifadelerinin standart sapmalarının düşük düzeyde olması bu konuda katılımcılar arasında fikir birliği olduğunu göstermektedir.

Destek kaynaklarda bölgenin en rekabetçi olduğu hususların turist güvenliği ve emniyetinin yeterliliği, yerel halkın turistlere yönelik cana yakınlık derecesi gibi ifadelerin olduğu tespit edilmiştir. Genel olarak bütün ifadelerin ortalamanın üstünde değerlere sahip olduğu destinasyon yönetiminde, Kapadokya Bölgesi'nin oldukça rekabetçi bir pozisyona sahip olduğu saptanmıştır. Durumsal koşullarda, özellikle destinasyonun sahip olduğu egzotikliğin (ilginç çekiciliklerin) yeterliliği ve turistlere konaklamak için harcadıkları paranın karşılığının verilme düzeyi ifadelerinin bölgenin sahip olduğu güçlü yönleri 
oluşturduğu ve bu ifadelere yönelik katılımcılar arasında bir fikir birliği olduğu görülmüştür. Ayrıca talep koşullarına yönelik değerler incelendiğinde, bu faktör altında yer alan bütün ifadelerin değerlerinin ortalamanın üzerinde yer aldığı ve bölgenin talep koşulları bakımından oldukça rekabetçi bir konuma sahip olduğu saptanmıştır.

Bütüncül bir yaklaşımla değerlendirildiğinde ise daimî kaynaklar (Omerzel 2006; Armenski vd. 2011; Komppula 2014; Pansiri 2014; Yüzbaşığlu vd. 2016), talep koşulları (Mulec ve Wise 2013; Vujko vd. 2016; Yüzbaşıŏlu vd. 2016), destinasyon yönetimi (Fernando ve Long 2012; Mulec ve Wise 2013; Hallman vd. 2014; Pansiri 2014), durumsal koşullar (Omerzel 2006; Mulec ve Wise 2013), yapay kaynaklar (Omerzel 2006; Komppula 2014) ve destek kaynaklar (Omerzel 2006; Vujko vd. 2016; Yüzbaşığlu vd. 2016) faktörlerinin ve bu faktörleri oluşturan ifadelerin Kapadokya Bölgesi'nin rekabetçilik bakımından güçlü yönlerini oluşturduğu söylenebilir. Bu manada, destinasyonları çekici kılan unsurların, turistlerin bir destinasyonun rekabetçiliğiyle ilgili sahip olduğu algıları olumlu veya olumsuz yönde etkileyebilen önemli etkenler oldukları ifade edilebilir.

Bu bilgi ve bulgular doğrultusunda, Kapadokya Bölgesi'nin sahip olduğu destinasyon rekabetçiliği pozisyonunun yükseltilebilmesi için önem arz eden ve bölgedeki sektör temsilcilerine yönelik önerilen hususlar şunlardır; (a) doğal ve yapay su kaynakları dâhilinde su aktivitelerinin artırılması, (b) eğlence ve temalı parkların yapılması, (c) alternatif spor tesisleriyle turistlere yönelik tesisleşmenin sağlanması, (ç) bölgeye ulaşımı kolaylaştırmak adına havaalanı koşullarının iyileştirilmesi ve uçuş sayılarının artırılması, (d) bölgeye olan talebin devamlılığın sağlanması için ortalama değerlere sahip olan bölgenin uçuş fiyatları, paket tur fiyatları ve rakiplere kıyasla tatil fiyatlarının konumunun korunması, (e) turistlerin tercihlerini bölgeye yönlendirecek, kalış sürelerini ve harcamalarını artıracak alternatif turizm faaliyetlerinin arttırılması, (f) gümrük büroları ve görevlileriyle ilgili düzenleyici faaliyetlerin yürütülmesi, (h) vizeyle ilgili maliyetleri ve yasal süreçleri azaltıcı yasal düzenlemelerin gerçekleştirilmesi, (1) bölgenin korunması ve sürdürülebi- lirliğinin sağlanması için gerekli yasal düzenlemelerin yapılması, (i) bölgenin etkinliğini artıracak destinasyon yönetim planları ve uygulamalarına yönelik yasal kolaylıkların sağlanması, (j) turist çekecek doğa ve macera aktivitelerinin çeşitlendirilmesi, (k) festival, konser gibi etkinliklerin arttırılması, (l) turistlerin ihtiyaçlarını karşılayabilmelerinin yanı sıra bölgeye ekonomik katkı sağlayacak alışveriş tesislerinin çeşitlendirilmesi ve (m) insan hayatı bakımından önemli olan sağlık tesislerine ve teknolojinin artmasıyla daha çok talep gören internet ve diğer iletişim araçlarına yönelik yatırımların arttırılması.

$\mathrm{Bu}$ araştırmanın, destinasyon rekabetçiliğiyle ilgili alan yazına katkılar sunmak amacıyla benzer konuyla ilgili gelecekte yapılacak araştırmalara yönelik birtakım önerileri bulunmaktadır: (a) Hem karşılaştırma yapabilmek hem de ilgili alanyazına derinlik kazandırmak için farklı kültür turizmi destinasyonlarına ve diğer alternatif turizm çeşitlerinin gerçekleştirildiği destinasyonlara yönelik destinasyon rekabetçiliği analizlerinin daha büyük evrenler dâhilinde yapılması önerilmektedir. (b) Araştırma sonuçlarının genellenebilirliğini arttırmak adına farklı örneklem yöntemleri ve tekniklerinden yararlanılması önerilmektedir. Ayrıca (c) Kapadokya Bölgesi'ne gelen turistlerin ülke olarak dağılımları oldukça farklılık gösterdiği için dil konusunda yaşanabilecek zorlukları ve zaman kayıplarını ortadan kaldırmak adına bu araştırmada, ölçek İngilizce olarak hazırlanmış ve İngilizce bilen turistlere (38 farklı ülke) ölçek uygulanmıştır. Dolayısıyla hem araştırma sonuçlarının ülkeler arasında karşılaştırılabilmesi hem de soruların anlaşılamamaS1, araştırma sorularına daha az önem verilmesi, araştırmanın amacı ve sonuçlarında sapmaların görülmesi gibi ortaya çıabilecek sorunların ortadan kaldırılması için belirlenmiş ülkelerden gelen turistlerin hedef kitle olarak seçilmesi ve bu doğrultuda kendi dillerinde soru formlarının hazırlanması ve uygulanması önerilmektedir.

\section{KAYNAKÇA}

Armenski, A., Vladimir, M., Nemanja D. ve Tamara, J. (2011). Integrated Model of Destinations Competitiveness, Geographica Pannonica, 15 (2): 58-69.

Bahar, O. ve Kozak, M. (2005). Türkiye Turizminin Akdeniz Ülkeleri ile Rekabet Gücü Açısından Karşılaştırılması, Anatolia: Turizm Araştırmaları Dergisi, 16 (2): 139-152. 
Bordas, E. (1994). Competitiveness of Tourist Destinations in Long Distance Markets, Tourism Review, 4 (3): 3-9.

Büyüköztürk, Ş. (2002). Faktör Analizi: Temel Kavramlar ve Ölçek Geliştirmede Kullanımı, Kuram ve Uygulamada Eğitim Yönetimi, 32 (32): 470-483.

Chens, C. Y., Sok, P. ve Sok, K. (2008). Evaluating the Competitiveness of the Tourism Industry in Cambodia: SelfAssessment from Professionals, Asia Pacific Journal of Tourism Research, 13 (1): 41-66.

Crouch, G. I. ve Ritchie, J. R. B. (1999). Tourism, Competitiveness and Societal Prosperity, Journal of Business Research, 44: 137-152.

Das, J. ve DiRienzo, C. E. (2009). Global Tourism Competitiveness and Freedom of the Press: A Nonlinear Relationship, Journal of Travel Research, 47 (4): 470-479.

Dwyer, L. ve Kim, C. (2003). Destination Competitiveness: Determinants and Indicators, Current Issues in Tourism, 6 (5): 369-414.

Enright, M. J. ve Newton, J. (2004). Tourism Destination Competitiveness: A Quantitative Approach, Tourism Management, 25: 777-788.

Fernando, I. N. ve Long, W. (2012). New Conceptual Model on Cluster Competitiveness: A New Paradigm for Tourism?, International Journal of Business and Management, 7 (9): 75-84.

Ferreira, J. M. ve Estevao, C. M. S. (2009). Regional Competitiveness of a Tourism Cluster: A Conceptual Model Proposal, Tourism \& Management Studies, 5: 37-51.

Fuller, E. (2013). Impact of the World's Travel/Tourism Industry Adds up to More than a Walk on the Beach, http://www.forbes.com/sites/edfuller /2013/12/03/impact-ofthe-worlds-traveltourism-industry-adds-up-to-more-thana-walk-on-the beach/\#4bd8a2646c25, Erişim tarihi: 24 Aralik 2016.

Gupta, S. ve Singh, A. (2015). Determinants of Tourism Destination Competitiveness: A Case of Bundelkhand, India, International Journal of Management Research, 6 (2): 47-62.

Gupta, S. ve Singh, A. (2019). Measurement Scale of Tourism Destination Competitiveness: Supply Side Perspectives, Journal of Indian Management, 16 (1): 105-116.

Güzel, Ö. (2010). Turistik Ürün Çeşitlendirmesi Kapsamında Yeni Bir Dinamik: İnanç Turizmi, Süleyman Demirel Üniversitesi Vizyoner Dergisi, 2 (2): 87-100.

Hallman, K., Müller, S. ve Feiler, S. (2014). Destination Competitiveness of Winter Sport Resorts in the Alps: How Sport Tourists Perceive Destinations?, Current Issues in Tourism, 17 (4): 327-349.

Hair, J. F., Anderson, R. E., Babin, B. J. ve Black, W. C. (2010). Multivariate Data Analysis: A Global Perspective. İngiltere: Cengage Learning EMEA.

Hassan, S. S. (2000). Determinants of Market Competitiveness in an Environmentally Sustainable Tourism Industry, Journal of Travel Research, 38: 239-245.

Heath, E. (2002). Towards a Model to Enhance Africa's Sustainable Tourism Competitiveness, Journal of Public Administration, 37 (3.1): 327-353.

Hertzog, M. A. (2008). Considerations in Determining Sample Size for Pilot Studies, Research in Nursing \& Health, 31: 180-191. http://www.surveysystem.com/sscalc.htm, Erişim tarihi: 23 Ekim 2019.

Johanson, G. A. ve Brooks, G. P. (2010). Initial Scale Development: Sample Size for Pilot Studies, Educational and Psychological Measurement, 70 (3): 394-400.

Karabulut, A. N. (2004). Küreselleşmenin Ticari Hayat Üzerindeki Etkileri, http://www.mevzuatdergisi. com/2004/04a/01.htm, Erişim tarihi: 30 Şubat 2017.

Karasar, N. (2014). Bilimsel Araştırma Yöntemi. Ankara: Nobel Yayınevi.

Kartal, Ö. (2010). Bodrum Tanitım Stratejisi, Bodrum Yarımadası Tanitma Vakf1 (BOYTAV), https://wwww.bodto.org.tr/ images/other/bts.pdf, Erişim tarihi: 03 Mart 2018.

Komppula, R. (2014). The Role of Individual Entrepreneurs in The Development of Competitiveness For a Rural Tourism Destination - A Case Study, Tourism Management, 40: 361-371.

Kültür ve Turizm Bakanlığı (2019). İstatistikler-Konaklama İstatistikleri-2017, http://yigm.kulturturizm.gov.tr/ TR,9856/konaklama-istatistikleri.html, Erişim tarihi: 23 Ekim 2019.

Meng, F. (2006). An Examination of Destination Competitiveness from the Tourists' Perspective: The Relationship between Quality of Tourism Experience and Perceived Destination Competitiveness. (Basılmamış Doktora Tezi). Virginia: Virginia Polytechnic Institute and State University.

Morgan, N., Pritchard, A. ve Pride, R. (2004). Destination Branding - Creating the Unique Destination Proposition. Oxford: Elsevier Science Ltd.

Mulec, I. ve Wise, N. (2013). Indicating the Competitiveness of Serbia's Vojvodina Region as an Emerging Tourism Destination, Tourism Management Perspectives, 8: 68-79.

Omerzel, D. G. (2006). Competitiveness of Slovenia as a Tourist Destination, Managing Global Transitions, 4 (2): 167189.

Pansiri, J. (2014). Tourist Motives and Destination Competitiveness: A Gap Analysis Perspective, International Journal of Hospitality \& Tourism Administration, 15: 217-247.

Porter, M. E. (1990). The Competitive Advantage of Nations. New York: The Free Press.

Ritchie, J.R.B. ve Crouch, G.I. (1993). Competitiveness in International Tourism: A Framework for Understanding and Analysis, Proceedings of the $43 \mathrm{rd}$ Congress of the Association Internationale d'Experts Scientifique du Tourisme (ss. 23-71). San Carlos de Bariloche, Arjantin.

Tsai, H., Song, H. ve Wong, K. K. F. (2009). Tourism and Hotel Competitiveness Research, Journal of Travel - Tourism Marketing, 26: 522-546.

Van Belle, G. (2002). Statistical Rules of Thumb. New York: John Will.

Vujko, A., Petrovic, M. D., Dragosavac, M. ve Gajic, T. (2016). Differences and Similarities Among Rural Tourism in Slovenia and Serbia - Perceptions of the Local Tourism Workers, Economics of Agriculture, 4 (63): 1459-1469.

Yazıcı, S. (2018). Kamu Yönetiminde Şeffaflık ve Hesap Verebilirliğin Toplumsal Algisı: Bir Alan Araştırması, Avrasya Uluslararası Araştırmalar Dergisi, 6 (14): 295-317. 
Yüzbaşıŏ̆lu, N., Çelik, P. ve Topsakal, Y. (2016). Antalya Destinasyonunun Turizm Rekabetçiliğinin Belirlenmesine Yönelik Ampirik Bir Çalışma. VIII. Lisansüstü Turizm Araştırmaları Kongresi (ss. 172-183). Türkiye: Nevşehir.
Zengin, B. ve Uyar, H. (2012). Türk Turizm ve Otelcilik Sektöründe Rekabet ve Rekabeti Etkileyen Faktörlerin Otel İşletmelerine Yönelik Olarak Değerlendirilmesi, Bartın Üniversitesi İ.I.B.F. Dergisi, 3 (5): 1-22.
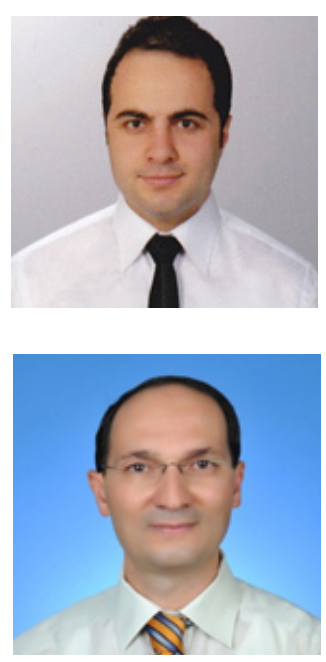

Mehmet Halit AKIN

Akdeniz Üniversitesi Turizm İşletmeciliği ve Otelcilik Yüksekokulu Konaklama İşletmeciliği Bölümü'nden mezun oldu (2009). Yüksek lisans derecesini Akdeniz Üniversitesi'nden Turizm İşletmeciliği Ana Bilim Dalı'ndan (2013), doktora derecesini ise Gazi Üniversitesi Turizm İşletmeciliği Ana Bilim Dalı'ndan aldı (2020). Gümüşhane Üniversitesi'nde çalışmaya başladı (2014). Halen Erciyes Üniversitesi Turizm Fakültesi'nde görev yapmaktadır (2016). Temel çalışma alanları, turizm işletmeciliği ve turizm pazarlamasıdır.

\section{Yüksel ÖZTÜRK}

Uludağ Üniversitesi, Balıkesir Turizm İşletmeciliği ve Otelcilik Yüksek Okulu'ndan lisans diplomasını aldı (1989). Aynı yıl Millı̂ Eğitim Bakanlığı'nın öğretim üyesi yetiştirmek üzere açmış olduğu yurtdışı sınavlarını kazanarak Fransa'ya gitti ve Université d'Aix-Marseille-3'ten Fransız Dili ve Edebiyatı Dalı'nda diploma almaya hak kazandı (1991). Manchester'da The University of Manchester Institute of Science and Technology'de bir yıl süre ile İngilizce dil eğitimi aldı (1992). Yüksek Lisans diplomasını İskoçya'da Strathclyde Üniversitesi İşletme Fakültesi'nden aldı (1993). Aynı üniversitede "Marketing Turkey as a Tourist Destination in the UK" konulu araştırması ile doktora derecesini aldı (1996). Gazi Üniversitesi, Ticaret ve Turizm Eğitimi Fakültesine Dr. Öğretim Görevlisi olarak başladı (1997) ve daha sonra sırasıyla yardımcı doçent (1999), pazarlama bilim alanında doçent (2003) ve profesörlük (2008) unvanlarını aldı. Halen Ankara Hacı Bayram Veli Üniversitesi Turizm Fakültesi'nde görev yapmaktadır. Temel çalışma alanları, turizm işletmeciliği ve turizm pazarlamasıdır.

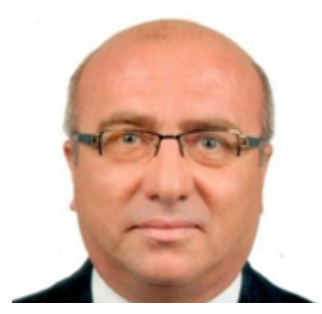

\section{Kurtuluş KARAMUSTAFA}

Çukurova Üniversitesi, İktisadi ve İdari Bilimler Fakültesi, Mersin Turizm İşletmeciliği ve Otelcilik Yüksekokulu'ndan (bugünkü Mersin Üniversitesi Turizm Fakültesi Turizm İşletmeciliği Bölümü'nden) mezun oldu (1991). Yüksek lisans derecesini Erciyes Üniversitesi'nden Turizm İşletmeciliği Ana Bilim Dalı'ndan (1993) aldı, doktora derecesini ise Strathclyde Üniversitesi İskoçya Otelcilik Okulu'ndan turizm alanından aldı (1999). Doçentlik unvanını pazarlama alanında (2006) ve profesörlük unvanını ise turizm pazarlaması alanında aldı (2011). Erciyes Üniversitesi'nde çalışmaya başladı (1991), halen Erciyes Üniversitesi Turizm Fakültesi'nde görev yapmaktadır ve aynı zamanda Kayseri Üniversitesi Rektörlüğü görevini de yürütmektedir. Temel çalışma alanları, turizm pazarlaması, turizm ve otel işletmeciliği ile araştırma yöntemleridir. 